\title{
Investigating incentives that encouraged and can encourage Polish and UK-based prosumers to engage in knowledge sharing
}

Ewa Ziemba, Faculty of Finance and Insurance, University of Economics in Katowice, ewa.ziemba@ue.katowice.pl

Monika Eisenbardt, Faculty of Finance and Insurance, University of Economics in Katowice, monika.eisenbardt@ue.katowice.pl

Roisin Mullins, Faculty of Business and Management, University of Wales Trinity Saint David, United Kingdom, r.mullins@uwtsd.ac.uk

Dariusz Grabara, Faculty of Finance and Insurance, University of Economics in Katowice, dariusz.grabara@ue.katowice.pl

\begin{abstract}
Prosumers' knowledge is increasingly becoming an integral and important element in business strategy regardless of the country. A major challenge for enterprises involves motivating prosumers to share their knowledge. This problem is addressed by incentives linked to the knowledge sharing activities of prosumers. Previous research showed that prosumers are willing to share knowledge, but only under the condition of obtaining certain benefits, rewards or fulfilling other personal goals in return. The purpose of this paper is to investigate which incentives encouraged and would encourage Polish and UK-based prosumers to engage in knowledge sharing with enterprises. The reported outcomes are the result of a questionnaire survey that yielded responses from 783 Polish and 171 UK-based prosumers. The results indicate there are statistically significant differences between Polish and UK-based prosumers in the particular choice of incentives that encouraged them and would encourage them to engage in knowledge sharing.
\end{abstract}

Keywords: consumer, prosumer, prosumption, enterprise, knowledge sharing, and incentives.

\section{Introduction}

Knowledge is a strategic advantage which helps enterprises sustain as well as maintain their market competitiveness (Grudzewski et al. 2013; Kisielnicki, 2014; Krupski, 2014; Nogalski \& Niewiadomski, 2013; Sopińska \& Wachowiak, 2015). Liebowitz (2003) claimed that knowledge related efforts could lead to effectiveness of an enterprise, its efficiency, and productivity. In the recent years, consumer knowledge:

- becomes an essential intangible asset for every line of business (Taherparvar, Esmaeilpour, \& Dostar, 2014);

- leads to a better response to and respect toward consumers (Aghamirian, Dorri, \& Aghamirian, 2013; Leadbeater, 2008; Reitz, 2012; Sinclaire \& Vogus, 2011; Tapscott \& Williams, 2006); 
- makes a contribution toward new and innovative products (Brabham, 2012; Gustafsson et al., 2011; Jurgenson \& Ritzer, 2009; Nasri, 2012; Tsai et al., 2012);

- estimates and responds to new market opportunities before competitors (Gibbert et al., 2002);

- creates new organizational inter-linkages with the customers to enhance the learning relationships within the enterprise teams (Gibbert et al., 2002);

- $\quad$ strengthens bonds between enterprises and prosumers (Morrison \& Crane, 2007; Mróz, 2013; Thomson, MacInnis, \& Park, 2005); and

- contributes to the improvement of business value (Croteau \& Li, 2003).

Practical cases confirm that incentives play an important role in knowledge sharing. The main objective of incentives was to encourage prosumers to engage in knowledge sharing. As the examples it is possible to list:

- Bank offers to clients tangible rewards in return for their ideas concerning banks' products and services development (e.g. Polish bank WBK has a portal for facilitating knowledge \& ideas sharing between the bank and prosumers);

- Portal Streetcom offers to prosumers tool-related and activity incentives as prosumers were invited to testing mobile applications of two Polish banks (mBank and Millenium Bank) before these applications were launching on the market;

- Polish radio offers to prosumers intangible (material) incentives as prosumers were invited to support the radio in the music choosing sphere (Polish radio - EscaRock);

- Public administration units offer to prosumers tangible and different intangible incentives to encourage prosumers in such activities as: logo, poster or statue designing, graphical elements creating, opinion sharing, etc.

Consumers who are active participants of knowledge exchange process and in turn share their knowledge with enterprises or other consumers, are known as prosumers; whereas prosumption means the process in which they actively share knowledge with enterprises (Bylok, 2013; Ritzer \& Jurgenson, 2010; Siuda, 2012; Tapscott \& Williams, 2006; Xie, Bagozzi, \& Troye, 2008). In general, prosumption refers to activities, which prosumers undertake to produce things of value for enterprises, as well as for themselves. They can share knowledge voluntary and do not expect any tangible benefits (Yuan, Lin, \& Zhuo, 2016). Other times they share knowledge under the condition of obtaining certain benefits in return, such as rewards or fulfilling personal goals (Ziemba \& Eisenbardt, 2016).

In the literature, researchers focused on two different attitudes of individuals toward knowledge sharing which affected the efficiency of knowledge sharing, i.e., willingness and eagerness to share knowledge (De Vries, Van den Hooff, \& De Ridder, 2006; Van den Hooff, De Ridder, \& Aukema, 2004; Tong, Tak, \& Wong, 2013). According to these researchers, prosumers are willing to share knowledge, but only under the condition of obtaining certain benefits in return, such as rewards or fulfilling other personal goals. Furthermore, eagerness for knowledge sharing means that prosumers have an internal drive to share knowledge. They share knowledge without 
reciprocity and do not expect any tangible benefits from their sharing. The prosumers' willingness and eagerness to share knowledge with enterprises were explored by Ziemba and Eisenbardt (2014). Hawkins et al. (2001) explored consumer behavior in building marketing strategies and recognized that 'new innovations help change components of consumer attitudes.' It may be argued that knowledge sharing is a behavioral response triggered by the need to achieve satisfaction from a social action. The marketing strategies investing in by enterprises are geared toward persuading the consumer to make a purchase and more recently in influencing behavior toward changing their attitudes by engaging them in reviewing and commenting on products and services indicated by Ikechukwu et al. (2012).

Dermol (2011) examined influences of organizational incentives on knowledge management. Ho and Kuo (2013) indicated that attitude toward incentives has shown a significant effect on knowledge sharing behavior in virtual communities of practice. A study in nine organizations, based in four countries, demonstrated that employees prefer 'soft' incentives for knowledge sharing like acknowledgments and personal development to increases in salary (Gammelgaard, 2007). Iyer and Ravindran (2009) explored the effect of 'usefulness' and 'incentives' on the joint decision to share and use the knowledge objects. The study found when the usefulness level is low an incentive mechanism that rewards the contributor for shared knowledge used by the knowledge user, and the knowledge user for the act of reuse, is more effective than a simple incentive scheme that merely rewards knowledge sharing.

Generally, the challenge is how to encourage prosumers to participate in knowledge sharing. Lam and Lambermont-Ford (2010) stressed that encouragement to knowledge sharing is a difficult task. Premazzi et al. (2010) examined customer's willingness to disclose information to e-vendors. The study revealed that although the customers did not indicate that incentives would make a difference, it seemed by the customers behavior that incentives may well play a part in their willingness to share information. However, this was also shown to be driven by a number of interesting attitude antecedents to sharing which requires further study.

As Liebowitz (2003) noted, some enterprises promote knowledge sharing and retain incentives and rewards until such processes become organizational norms. Therefore, enterprises that have successfully encouraged knowledge sharing among prosumers have exhibited improved organizational performance.

Overall, researchers agree that despite the voluminous literature on knowledge management, the association between individual motivation and knowledge sharing remains largely unexplored and poorly understood (Gafni, Geri, \& Bengov, 2014; Lam \& Lambermont-Ford, 2010). Furthermore, after extensively searching the literature, the authors of this paper could not uncover any deep studies concerning motivation and prosumers' encouragement to knowledge sharing. Thus, there is a need for studying incentives and rewards affecting prosumers' knowledge sharing. This research carried out among Polish and UK-based prosumers should contribute to greater understanding of the use of incentives for prosumers' knowledge sharing and should help fill the gap in the existing body of knowledge.

In light of the above limitations, the purpose of this study is to investigate which incentives encouraged and would encourage Polish and UK-based prosumers to engage in knowledge sharing with enterprises or other prosumers. Thus, the literature was reviewed, a survey questionnaire was developed, and statistical analysis was employed. The paper is organized as 
follows: the research questions and hypotheses followed by the research methodology; then results, analysis, and discussion are provided; and the paper concludes with a summary, limitations, and avenues for future research.

\section{Research Questions and Hypotheses}

Some authors stress that an incentive system has a significant affect on knowledge sharing (Cheng, Ho, \& Lau, 2009). An incentive system and a personal expectation are two significant factors associated with a passion for sharing knowledge. Researchers proved that most crowdsourcing platform participants in some popular areas compete for tasks, while many tasks in unpopular areas cannot be completed due to the lack of participants (Tian et al., 2017). They designed a movement-based incentive mechanism for crowdsourcing, where participants are stimulated to move to the unpopular areas and complete the sensing tasks in these areas. Van Aken, Camps, and Jurgens (1998) suggested that a number of organizational factors can have a negative effect on motivating individuals to share knowledge while Hall (2001) considered five areas that organizations should address to actively encourage knowledge sharing, but again these are inter-organizational strategies focusing on employers. Thus, enterprises should implement the conditions to promote knowledge sharing and use various incentives to encourage prosumers to engage in knowledge sharing (Humphreys \& Grayson, 2008; Gafni et al., 2014).

A considerable number of scholars employed a dichotomous method that divides incentives into two parts: intrinsic and extrinsic (Ho \& Kuo, 2013; Löcker et al., 2014). Intrinsic incentives refer to doing something because it is inherently interesting or enjoyable, while extrinsic incentives refer to doing something because it leads to a separable outcome, e.g., money, promotion, profits, career progression, etc. (Ryan \& Deci, 2000).

Another group of scholars separated the incentives to encourage knowledge sharing into two types: tangible and intangible (Chouikha, 2016; Janzik \& Herstatt, 2008; Vuori \& Okkonen, 2012). Tangible incentives mainly include monetary compensation, bonus points with financial value, and premiums in the form of free products. There are also intangible incentives enhancing the expertise, status, reputation, and recognition of individuals. These kinds of incentives also embrace being part of a community, a pride in excellence, and a need to learn more.

Furthermore, Greenberg and Liebman (1990) suggested that incentives fall into three categories: material, social and activity. Material incentives comprise revenue and financial benefit. Social incentives operate on the interpersonal level by allowing people to identify themselves with the company, co-workers, customers or even competitors. Activity incentives provide opportunities to fulfill individual needs of achievement or growth by offering more new and challenging tasks. Ho and Kuo (2013) confirmed that these kinds of incentives have demonstrated significant influences on the community participants' knowledge sharing behavior.

After extensive searching of the literature, only a few studies were found regarding types of incentives encouraging prosumers to knowledge sharing with enterprises. The case studies described by Ziemba and Eisenbardt (2015) indicate that enterprises increasingly use various incentives to encourage prosumers to share knowledge, mainly financial rewards, possibility of adjusting products/services to own needs, building reputation in a society, receiving free samples of products, receiving vouchers, and creating active social networks of customers. Ziemba and 
Eisenbardt (2016) proposed a framework of incentives encouraging prosumers to engage in knowledge sharing. This framework included tangible and intangible incentives. The named intangible incentives were categorized into activity, social, tool- and promotion-related incentives. Based on a questionnaire survey producing data from 783 Polish prosumers, it was identified that tangible and activity incentives mainly encourage prosumers to engage in knowledge sharing. Prosumers award slightly less points to social incentives. Meanwhile, tooland promotion-related incentives have the lowest impact on prosumers' knowledge sharing. Moreover, it was found that there are significant relationships between prosumers' gender and all types of incentives, between generations and tangible incentives, as well as between educational background and tangible, activity, social, and tool-related incentives.

Following an extensive literature search, no studies concerning incentives that encouraged and would encourage prosumers to engage in knowledge sharing in other countries or even comparisons between countries were found. Therefore, the paper examines incentives that encouraged and would encourage Polish and UK-based prosumers to engage in knowledge sharing.

The paper focuses on addressing the following research questions:

Q1: What incentives encouraged Polish and UK-based prosumers to engage in knowledge sharing?

Q2: Are there statistically significant differences between Polish and UK-based prosumers in the choice of incentives that encouraged them to engage in knowledge sharing?

Q3: What incentives would encourage Polish and UK-based prosumers to engage in knowledge sharing?

Q4: Are there statistically significant differences between Polish and UK-based prosumers combined in the choice of incentives that would encourage them to engage in knowledge sharing?

Q5: Are there statistically significant differences between the choice of incentives that encouraged and would encourage Polish and UK-based prosumers to engage in knowledge sharing?

Q6: What incentives encouraged Polish prosumers to engage in knowledge sharing?

Q7: What incentives would encourage Polish prosumers to engage in knowledge sharing?

Q8: Are there statistically significant differences between incentives that encouraged and would encourage Polish prosumers to engage in knowledge sharing?

Q9: What incentives encouraged UK-based prosumers to engage in knowledge sharing?

Q10: What incentives would encourage UK-based prosumers to engage in knowledge sharing?

Q11: Are there statistically significant differences between incentives that encouraged and would encourage UK-based prosumers to engage in knowledge sharing?

Taking into account the above considerations and above research questions, five research hypotheses were formulated: 
H1: There are statistically significant differences between Polish and UK-based prosumers in incentives that encouraged them to engage in knowledge sharing.

H2: There are statistically significant differences between Polish and UK-based prosumers in incentives that would encourage them to engage in knowledge sharing.

H3: There are statistically significant differences between incentives that encouraged and would encourage Polish and UK-based prosumers (combined) to engage in knowledge sharing.

H4: There are statistically significant differences between incentives that encouraged and would encourage Polish prosumers to engage in knowledge sharing.

H5: There are statistically significant differences between incentives that encouraged and would encourage UK-based prosumers to engage in knowledge sharing.

\section{Research Methodology}

Research methods included a critical review of the literature, logical deduction, case studies, a survey questionnaire, and statistical analysis. The research process took the following steps:

Step 1. A critical review of existing studies related to 'prosumption', 'prosumer', 'customer', 'consumer', 'knowledge sharing', 'incentives', and 'rewards' enabled examination of incentives encouraging consumers/prosumers to knowledge sharing. The review embraces four bibliographic databases: Ebsco, ProQuest, Emerald Management, and ISI Web of Knowledge. In addition, some journals and Web materials dedicated to research on 'consumption' and 'prosumption' were also explored.

Step 2. Case studies of prosumers' knowledge sharing indicate that prosumers are expecting some incentives from enterprises to share knowledge (Ziemba \& Eisenbardt, 2015). Based on the analysis of incentives that enterprises can use to encourage prosumers to share knowledge, a conceptual framework of incentives for prosumers to share knowledge was proposed.

Step 3. An initial pilot survey questionnaire was designed. The questionnaire was divided into two parts. After a few demographics questions, all participants were obliged to answer the question: Have you ever assessed or commented on products or companies, proposed products improvements to the companies or designed new products? This question enabled the division of respondents into consumers (not active in this area) and prosumers (active ones). The questionnaire contained questions concerning specified incentives encouraging prosumers to knowledge sharing.

The questions were: (1) Which incentives offered by enterprises encouraged you to engage in knowledge sharing with enterprises? (2) Which incentives would encourage you to engage in knowledge sharing with enterprises? The former question was directed only to prosumers. The latter was directed to both - prosumers and consumers. The incentives were listed for these questions (see Appendix 1). For each listed incentive the respondents could choose one of five responses, according to a 5-point Likert scale: (1) definitely no, (2) rather no, (3) neither yes nor no, (4) rather yes, (5) definitely yes. 
Step 4. In November 2014 the more in-depth pilot survey was conducted in Poland. The purpose was substantive and methodological scrutiny of the questionnaire. To conduct reliability analysis, Cronbach's coefficient alpha was used. For all analyzed items the Cronbach's alpha was 0.881. Hinton (2004) suggested four ranges of reliability, i.e., the excellent range (0.90 and above), the high (0.70-0.90), the high moderate (0.50-0.70) and the low (0.50 and below). Thus, it can be concluded that the scale had high reliability, and it could be used in the research process. Moreover, substantive scrutiny of the questionnaire enabled to perform minor changes to improve the quality of the questionnaire.

Step 5. Applying the Computer-Assisted Web Interview (CAWI) method and employing the Polish platform Ankietka.pl, and the English platform Bristol Online Survey (BOS), hosted at the University of Bristol, the survey questionnaire was uploaded to the website. Data collection took place between the end of December 2014 and March 2015 in Poland, and between February and April 2016 in the United Kingdom. In Poland, the designed sample size was 2,500 people, comprising people of different age, gender, and ICT skills. In the UK the online survey letter and URL was initially posted to 1,000 individuals comprising people of different age, gender, and ICT skills, and presented to a random sample of the target population. Using online tools permits contact with an accessible audience as the survey appears on search engine lists due to metatags and appropriate placing of keywords. After screening the responses and excluding outliers, there was a final research sample of 783 usable, correct and complete questionnaires from Poland and 171 from the United Kingdom. The data was stored in Microsoft Excel format. The demographic analysis of the research sample is presented in Table 1.

Table 1: Demographic analysis of the research sample

\begin{tabular}{|c|c|c|c|c|}
\hline \multirow[b]{2}{*}{ Demographic profile } & \multicolumn{2}{|c|}{ Poland } & \multicolumn{2}{|c|}{ United Kingdom } \\
\hline & $\begin{array}{l}\text { Number of } \\
\text { respondents }\end{array}$ & Percentage & $\begin{array}{l}\text { Number of } \\
\text { respondents }\end{array}$ & Percentage \\
\hline \multicolumn{5}{|l|}{ Gender } \\
\hline female & 599 & $76.5 \%$ & 98 & $57.3 \%$ \\
\hline male & 184 & $23.5 \%$ & 73 & $42.7 \%$ \\
\hline \multicolumn{5}{|l|}{ Age } \\
\hline Builders generation: over 65 years old & 14 & $1.8 \%$ & 8 & $4.68 \%$ \\
\hline Baby-Boomers generation: 51-65 years old & 35 & $4.5 \%$ & 25 & $14.62 \%$ \\
\hline X generation: $36-50$ years old & 108 & $13.8 \%$ & 67 & $39.18 \%$ \\
\hline Y generation: $21-35$ years old & 369 & $47.1 \%$ & 68 & $39.77 \%$ \\
\hline Z generation: less than 21 years old & 257 & $32.8 \%$ & 3 & $1.75 \%$ \\
\hline \multicolumn{5}{|l|}{ Level of education } \\
\hline higher education & 217 & $27.7 \%$ & 89 & $52.05 \%$ \\
\hline secondary education & 559 & $71.4 \%$ & 75 & $43.86 \%$ \\
\hline less than secondary education & 7 & $0.9 \%$ & 7 & $4.09 \%$ \\
\hline \multicolumn{5}{|l|}{ Place of residence } \\
\hline city with a population of more than 100,000 & 419 & $53.5 \%$ & 96 & $56.14 \%$ \\
\hline city with a population of less than 100,000 & 244 & $31.2 \%$ & 53 & $30.99 \%$ \\
\hline rural area & 120 & $15.3 \%$ & 22 & $12.87 \%$ \\
\hline
\end{tabular}


Step 6. As the process of collecting data was completed the reliability was calculated. The Cronbach's alpha coefficient with all 23 items confirmed a high internal consistency (0.791). Then, reliability was calculated for each type of incentives and each item. For tangible incentives Cronbach's alpha coefficient was 0.825 (6 items), for activity incentives it was 0.732 (5 items), for social incentives it was 0.759 (3 items), for tool-related incentives it was 0.786 (6 items), and for promotion-related it was 0.628 ( 3 items). Cronbach's alpha for promotion related incentives is smaller than the threshold, and DeVellis (2003) suggests that a low value of alpha could be due to a low number of questions, poor inter-relatedness between items, or heterogeneous constructs. In this case, it was limited to only three items. It is suggested that where a low alpha is due to poor correlation between items, then some should be revised or discarded. In addition, it was determined that the removal of some items would not lead to the significant improvement of internal consistency among items on the scale. Therefore, it was decided that for further analyses all 23 items would be used along with five types of incentives.

Step 7. In order to answer the research questions and confirm the research hypotheses, the statistical analysis was employed. Firstly, the descriptive analysis was employed to describe incentives that encouraged and would encourage prosumers to knowledge sharing. The following statistics were calculated: mean, median (MDN), first quartile (Q25), third quartile (Q75), mode, variance (VAR), standard deviation (SD), coefficient of variation (CV), skewness (SK), and coefficient of kurtosis (CK). Secondly, the Mann-Whitney U test was applied in order to identify differences between Polish and UK-based prosumers, and between incentives that encouraged and would encourage prosumers to engage in knowledge sharing. This test was selected because it does not assume any assumptions related to the distribution, and it is used to test whether two independent samples of observations are drawn from the same or identical distribution. The statistical analysis was made using MS Excel and Statistica software.

\section{Research Findings}

\section{Framework of Incentives to Encourage Prosumers to Engage in Knowledge Sharing}

In further analyses, a conceptual framework (Appendix 1) described in (Ziemba \& Eisenbardt, 2016) was adopted. The framework divides incentives into five types (the code of each type of incentive is given in the bracket):

- Tangible incentives (TAN);

- Intangible incentives - activity incentives (ACT);

- Intangible incentives - social incentives (SOC);

- Intangible incentives - tool-related incentives (TOL); and

- Intangible incentives - promotion-related incentives (PRO).

Within the proposed framework a distinction is made between tangible and intangible incentives. Concerning the tangible incentives, there are such incentives as direct financial incentives (e.g. monetary compensation) and indirect financial incentives (e.g. premiums in the form of free 
products, bonus points with financial value). The named intangible incentives are categorized as followed (Ziemba \& Eisenbardt, 2016):

- activity incentives provide opportunities to collaborate with enterprises and co-create things of value by providing more new, innovative and challenging tasks;

- social incentives operate on the interpersonal level by allowing prosumers to identify themselves with the enterprise communities, build their reputation and status, enhance skills, and collect knowledge and experience;

- tool-related incentives refer to ICTs, especially tools for online communities, which encourage prosumers to integrate with enterprises' communities; and

- promotion-related incentives are related to promotional activities of enterprises encouraging prosumers to knowledge sharing and co-creating promotional materials.

In order to analyze types of incentives that are crucial for prosumers, we examined incentives that encouraged and would encourage Polish and UK-based prosumers to engage in knowledge sharing. The analyses were made in the context of Poland and UK combined, as well as separately in Poland and the UK. Incentives that encouraged prosumers are these incentives which prosumers used in knowledge sharing in the past. Whereas, incentives that would encourage prosumers reflect these incentives which are needed by prosumers to engage in knowledge sharing.

\section{Incentives that Encouraged Polish and UK-based Prosumers to Engage in Knowledge Sharing}

The following research questions and hypothesis were posed and relate to the combined results regarding incentives encouraged prosumers to engage in knowledge sharing in Poland and the UK.

Q1: What incentives encouraged Polish and UK-based prosumers to engage in knowledge sharing?

Q2: Are there statistically significant differences between Polish and UK-based prosumers in the choice of incentives that encouraged them to engage in knowledge sharing?

H1: There are statistically significant differences between Polish and UK-based prosumers in incentives that encouraged them to engage in knowledge sharing.

In order to answer the research question Q1, detailed analysis concerning incentives encouraged Polish and UK-based prosumers to engage in knowledge sharing, was made. The results are presented in Table 2. It is found that prosumers were mainly encouraged by activity incentives and slightly less by tangible and social incentives. No incentive exceeded the mean value of 3.15. What is more, median values are 3 in case of activity, tangible, and social incentives, and 2 in case of tool-related and promotion-related incentives. It could indicate that prosumers did not have straight opinion about incentives which encouraged them to engage in knowledge sharing. 
Table 2: Incentives that encouraged Polish and UK-based prosumers combined to engage in knowledge sharing

\begin{tabular}{|l|r|r|r|r|r|r|r|r|r|r|}
\hline $\begin{array}{l}\text { Types of } \\
\text { incentives }\end{array}$ & Mean & \multicolumn{1}{c|}{ Q25 } & MDN & Q75 & Mode & VAR & SD & CV & SK & CK \\
\hline ACT & 3.15 & 3 & 3 & 4 & 3 & 0.67 & 0.82 & 0.26 & 0.18 & 0.08 \\
\hline TAN & 2.84 & 2 & 3 & 4 & 1 & 1.06 & 1.03 & 0.36 & 1.79 & -0.85 \\
\hline SOC & 2.83 & 2 & 3 & 3 & 2 & 1.04 & 1.02 & 0.36 & 0.82 & -0.53 \\
\hline TOL & 2.46 & 2 & 2 & 3 & 2 & 0.73 & 0.85 & 0.35 & 0.54 & -0.79 \\
\hline PRO & 2.24 & 2 & 2 & 3 & 2 & 0.71 & 0.84 & 0.37 & 0.29 & -0.14 \\
\hline
\end{tabular}

In order to answer the research question Q2 about significant differences between Polish and UK-based prosumers in the choice of incentives that encouraged them to engage in knowledge sharing, the Mann-Whitney $U$ test was used. The test results presented in Table 3 did not show any significant differences between Polish and UK-based prosumers only in case of promotionrelated incentives. Whereas there were significant differences between Polish and UK-based prosumers in case of tangible, activity, social, and tool-related incentives.

Table 3: The Mann-Whitney test results for incentives that encouraged Polish and UK-based prosumers to engage in knowledge sharing

\begin{tabular}{|l|r|r|r|r|r|}
\hline $\begin{array}{l}\text { Types of } \\
\text { incentives }\end{array}$ & TAN & \multicolumn{1}{c|}{ ACT } & \multicolumn{1}{c|}{ SOC } & \multicolumn{1}{c|}{ TOL } & PRO \\
\hline $\mathbf{Z}$ & -3.07 & -3.68 & -3.65 & -4.48 & -0.34 \\
\hline $\mathbf{p}$ value & 0.00 & 0.00 & 0.00 & 0.00 & 0.74 \\
\hline
\end{tabular}

The detailed analysis (Appendix 2) shows that:

- Tangible incentives encouraged more UK-based prosumers (Mean=3.19; MDN=3; Mode=4) than Polish prosumers (Mean=2.78; $\mathrm{MDN}=3$; Mode=1);

- Activity incentives encouraged more UK-based prosumers (Mean=3.49; MDN=4; Mode=3) than Polish prosumers (Mean=3.08; $\mathrm{MDN}=3$; Mode=3);

- Social incentives encouraged more UK-based prosumers (Mean=3.30; $\mathrm{MDN}=3$; Mode=2) than Polish prosumers (Mean=2.74; MDN=3; Mode=2); and

- Tool-related incentives encouraged more UK-based prosumers (Mean=2.86; MDN=3; Mode=3) than Polish prosumers (Mean=2.39; MDN=2; Mode=2).

\section{Incentives that Would Encourage Polish and UK-based Prosumers to Engage in Knowledge Sharing}

The following research questions and hypothesis related to incentives that would encourage Polish and UK-based prosumers combined to engage in knowledge sharing were posed: 
Q3: What incentives would encourage Polish and UK-based prosumers combined to engage in knowledge sharing?

Q4: Are there statistically significant differences between Polish and UK-based prosumers combined in the choice of incentives that would encourage them to engage in knowledge sharing?

H2: There are statistically significant differences between Polish and UK-based prosumers in incentives that would encourage them to engage in knowledge sharing.

In order to answer the research question Q3 detailed analysis concerning incentives that would encourage Polish and UK-based prosumers to engage in knowledge sharing was made. The results are presented in Table 4. It is found that prosumers would encourage mainly tangible incentives. The mean value is 3.65 , the median and the mode values are 4 . Other incentives would encourage prosumers to engage in knowledge sharing but in lesser range (activity and social ones) or would not encourage them (tool-related and promotion-related ones).

Table 4: Incentives that would encourage Polish and UK-based prosumers combined to engage in knowledge sharing

\begin{tabular}{|l|r|r|r|r|r|r|r|r|r|r|}
\hline $\begin{array}{l}\text { Types of } \\
\text { incentives }\end{array}$ & Mean & Q25 & MDN & Q75 & Mode & VAR & \multicolumn{1}{c|}{ SD } & CV & \multicolumn{1}{l|}{ SK } & CK \\
\hline TAN & 3.65 & 3 & 4 & 4 & 4 & 0.57 & 0.76 & 0.21 & -0.03 & 1.06 \\
\hline ACT & 3.35 & 3 & 3 & 4 & 4 & 0.59 & 0.77 & 0.23 & -0.42 & 0.54 \\
\hline SOC & 3.26 & 3 & 3 & 4 & 4 & 1.02 & 1.01 & 0.31 & -0.74 & -0.55 \\
\hline TOL & 2.70 & 2 & 3 & 3 & 3 & 0.70 & 0.84 & 0.31 & -0.36 & -0.04 \\
\hline PRO & 2.57 & 2 & 3 & 3 & 2 & 0.74 & 0.86 & 0.33 & 0.66 & -0.09 \\
\hline
\end{tabular}

In order to answer the research question Q4 about significant differences between Polish and UK-based prosumers in the choice of incentives that would encourage them to engage in knowledge sharing, the Mann-Whitney $U$ test was used. The test results presented in Table 5 did not show any significant differences between Polish and UK-based prosumers only in case of tool-related incentives. Whereas there were significant differences in case of tangible, activity, social, and promotion-related incentives.

Table 5: The Mann-Whitney test results for incentives that would encourage Polish and UKbased prosumers to engage in knowledge sharing

\begin{tabular}{|l|r|r|r|r|r|}
\hline $\begin{array}{l}\text { Types of } \\
\text { incentives }\end{array}$ & TAN & ACT & SOC & TOL & PRO \\
\hline $\mathbf{Z}$ & 7.78 & 3.56 & 4.62 & -1.95 & 6.32 \\
\hline p value & 0.00 & 0.00 & 0.00 & 0.05 & 0.00 \\
\hline
\end{tabular}

The detailed analysis (Appendix 2) shows that:

- Tangible incentives would encourage more Polish prosumers (Mean=3.74; MDN=4; Mode=4) than UK-based prosumers $($ Mean=3.23; $\mathrm{MDN}=3$; Mode=3); 
- Activity incentives would encourage more Polish prosumers (Mean=3.38; MDN=4; Mode $=4$ ) than UK-based prosumers (Mean=3.18; $\mathrm{MDN}=3$; Mode=3);

- Social incentives would encourage more Polish prosumers (Mean=3.32; MDN=3; Mode=4) than UK-based prosumers (Mean=2.97; MDN=3; Mode=2); and

- Promotion-related incentives would encourage more Polish prosumers (Mean=2.64; $\mathrm{MDN}=3$; Mode=2) than UK-based prosumers (Mean=2.25; MDN=2; Mode=2).

\section{Comparison Between Incentives that Encouraged and Would Encourage Polish and UK-based Prosumers to Engage in Knowledge Sharing}

The following research question and hypothesis were posed related to a comparison between incentives that encouraged and would encourage Polish and UK-based prosumers combined to engage in knowledge sharing:

Q5: Are there statistically significant differences between the choice of incentives that encouraged and would encourage Polish and UK-based prosumers to engage in knowledge sharing?

H3: There are statistically significant differences between incentives that encouraged and would encourage Polish and UK-based prosumers (combined) to engage in knowledge sharing.

In order to answer the research question Q5 about significant differences between incentives that encouraged and incentives that would encourage Polish and UK-based prosumers combined to engage in knowledge sharing, the Mann-Whitney $U$ test was used. The test results presented in Table 6 show that there were significant differences in incentives that encouraged and would encourage Polish and UK-based prosumers combined to engage in knowledge sharing.

Table 6: The Mann-Whitney test results for incentives that encouraged and would encourage Polish and UK-based prosumers combined to engage in knowledge sharing

\begin{tabular}{|l|r|r|r|r|r|}
\hline $\begin{array}{l}\text { Types of } \\
\text { incentives }\end{array}$ & \multicolumn{1}{|c|}{ TAN } & \multicolumn{1}{c|}{ ACT } & \multicolumn{1}{c|}{ SOC } & \multicolumn{1}{c|}{ TOL } & PRO \\
\hline $\mathbf{Z}$ & -14.12 & -4.20 & -7.32 & -4.47 & -6.40 \\
\hline $\mathbf{p}$ value & 0.00 & 0.00 & 0.00 & 0.00 & 0.00 \\
\hline
\end{tabular}

The detailed analysis (Appendix 2) shows that:

- Tangible incentives would more likely encourage Polish and UK-based prosumers (Mean=3.65; MDN=4; Mode=4) than encouraged them in the past $(\mathrm{Mean}=2.92 ; \mathrm{MDN}=3$; Mode=3); 
- Activity incentives would slightly more encourage Polish and UK-based prosumers $($ Mean=3.35; $\mathrm{MDN}=3 ;$ Mode=4) than encouraged them in the past $(\mathrm{Mean}=3.15 ; \mathrm{MDN}=3$; Mode=3);

- Social incentives would more likely encourage Polish and UK-based prosumers $(M e a n=3.26 ; M D N=3 ;$ Mode=4) than encouraged them in the past $(M e a n=2.83 ; M D N=3$; Mode=2);

- Tool-related incentives would more likely encourage Polish and UK-based prosumers $($ Mean=2.70; $\mathrm{MDN}=3 ;$ Mode=3) than encouraged them in the past $(\mathrm{Mean}=2.46 ; \mathrm{MDN}=2$; Mode=2); and

- Promotion-related incentives would more likely encourage Polish and UK-based prosumers (Mean=2.57; $\mathrm{MDN}=3 ; \mathrm{Mode}=2$ ) than encouraged them in the past $($ Mean=2.24; $\mathrm{MDN}=2 ;$ Mode=2).

\section{Incentives that Encouraged and Would Encourage Polish Prosumers to Engage in Knowledge Sharing}

The following research questions and hypothesis related to a comparison between incentives that encouraged and would encourage Polish prosumers to engage in knowledge sharing were posed:

Q6: What incentives encouraged Polish prosumers to engage in knowledge sharing?

Q7: What incentives would encourage Polish prosumers to engage in knowledge sharing?

Q8: Are there statistically significant differences between incentives that encouraged and would encourage Polish prosumers to engage in knowledge sharing?

H4: There are statistically significant differences between incentives that encouraged and would encourage Polish prosumers to engage in knowledge sharing.

In order to answer the research questions Q6 and Q7, detailed analysis concerning incentives that encouraged and would encourage Polish prosumers to engage in knowledge sharing was made. The results are presented in Table 7 (ordered by mean values of incentives that would encourage). It is found that Polish prosumers mainly were encouraged by activity, tangible, and social incentives. Nonetheless, it is worth to underline that all mean values are quite low, and not exceed the value 3.08. Additionally, the median values are 3 in these three cases. It may mean that Polish prosumers did not have a clear opinion about incentives that encouraged them in the past to engage in knowledge sharing. In case of incentives that would encourage Polish prosumers, tangible incentives yielded the largest range of encouragement. Mean value is 3.74, median is 4 . However, all types of incentives are more needed by Polish prosumers and would encourage them to share knowledge. Especially tangible ones are most expected - the difference between mean values for incentives that encouraged and would encourage is almost 1, indicating that prosumers would expect these incentives to engage in knowledge sharing. 
Table 7: Incentives that encouraged and would encourage Polish prosumers to engage in knowledge sharing

\begin{tabular}{|l|r|r|r|r|r|r|r|r|r|r|r|r|}
\hline \multirow{2}{*}{$\begin{array}{l}\text { Types of } \\
\text { incentives }\end{array}$} & \multicolumn{5}{|c|}{ Incentives that encouraged } & \multicolumn{5}{|c|}{ Incentives that would encourage } \\
\cline { 2 - 14 } & Mean & Q25 & MDN & Q75 & CV & SK & Mean & Q25 & MDN & Q75 & CV & SK \\
\hline TAN & 2.78 & 2 & 3 & 4 & 0.37 & 1.71 & 3.74 & 3 & 4 & 4 & 0.19 & 0.10 \\
\hline ACT & 3.08 & 3 & 3 & 4 & 0.26 & 0.10 & 3.38 & 3 & 4 & 4 & 0.22 & -0.39 \\
\hline SOC & 2.74 & 2 & 3 & 3 & 0.35 & 0.77 & 3.32 & 3 & 3 & 4 & 0.30 & -0.69 \\
\hline TOL & 2.39 & 2 & 2 & 3 & 0.36 & 0.45 & 2.67 & 2 & 3 & 3 & 0.32 & -0.38 \\
\hline PRO & 2.24 & 2 & 2 & 3 & 0.39 & 0.27 & 2.64 & 2 & 3 & 3 & 0.33 & 0.74 \\
\hline
\end{tabular}

In order to answer the research question Q8 about significant differences between incentives that encouraged and would encourage Polish prosumers to engage in knowledge sharing, the MannWhitney $U$ test was used. The test results presented in Table 8 show that there were significant differences in case of each type of incentives.

Table 8: The Mann-Whitney test results for incentives that encouraged and would encourage Polish prosumers to engage in knowledge sharing

\begin{tabular}{|l|r|r|r|r|r|}
\hline $\begin{array}{l}\text { Types of } \\
\text { incentives }\end{array}$ & \multicolumn{1}{|c|}{ TAN } & \multicolumn{1}{c|}{ ACT } & \multicolumn{1}{c|}{ SOC } & \multicolumn{1}{c|}{ TOL } & \multicolumn{1}{c|}{ PRO } \\
\hline $\mathbf{Z}$ & -15.31 & -6.11 & -9.35 & -5.12 & -7.15 \\
\hline $\mathbf{p}$ value & 0.00 & 0.00 & 0.00 & 0.00 & 0.00 \\
\hline
\end{tabular}

The detailed analysis (Appendix 2) shows that:

- Tangible incentives would more likely encourage Polish prosumers (Mean=3.74; $\mathrm{MDN}=4 ;$ Mode $=4)$ than encouraged them in the past $($ Mean=2.84; $\mathrm{MDN}=3 ; \operatorname{Mode}=1)$;

- Activity incentives would more likely encourage Polish prosumers (Mean=3.38; $\mathrm{MDN}=4 ;$ Mode=4) than encouraged them in the past (Mean=3.08; $\mathrm{MDN}=3 ;$ Mode=3);

- Social incentives would more likely encourage Polish prosumers (Mean=3.32; MDN=3; Mode=4) than encouraged them in the past $($ Mean=2.73; MDN=3; Mode=2);

- Tool-related incentives would more likely encourage Polish prosumers (Mean=2.67; $\mathrm{MDN}=3 ;$ Mode=3) than encouraged them in the past (Mean=2.39; MDN=2; Mode=2); and

- Promotion-related incentives would more likely encourage Polish prosumers $($ Mean=2.64; $\mathrm{MDN}=3 ;$ Mode=2) than encouraged them in the past $(\mathrm{Mean}=2.24 ; \mathrm{MDN}=2$; Mode=2). 


\section{Incentives that Encouraged and Would Encourage UK-based Prosumers to Engage in Knowledge Sharing}

The following research questions and hypothesis related to a comparison between incentives that encouraged and would encourage UK-based prosumers to engage in knowledge sharing were posed:

Q9: What incentives encouraged UK-based prosumers to engage in knowledge sharing?

Q10: What incentives would encourage UK-based prosumers to engage in knowledge sharing?

Q11: Are there statistically significant differences between incentives that encouraged and would encourage UK-based prosumers to engage in knowledge sharing?

H5: There are statistically significant differences between incentives that encouraged and would encourage UK-based prosumers to engage in knowledge sharing.

In order to answer the research questions Q9 and Q10, detailed analysis concerning incentives that encouraged and would encourage UK-based prosumers to engage in knowledge sharing was made. The results are presented in Table 9. It is found that in case of UK-based prosumers the mean and median values of incentives that encouraged and would encourage prosumers to engage in knowledge sharing are similar and in both cases are rather low. The difference between mean values for incentives that encouraged and would encourage UK-based prosumers do not exceed 0.33 . It is worth to notice that in case of activity and social incentives the mean values of incentives that encouraged prosumers in the past are higher than mean values of incentives that would encourage them in the future. Additionally, the median values do not exceed 3. It means that prosumers do not have straight opinion or prosumers are reluctant about incentives that encouraged or would encourage them to engage in knowledge sharing.

Table 9: Incentives that encouraged and would encourage UK-based prosumers to engage in knowledge sharing

\begin{tabular}{|l|r|r|r|r|r|r|r|r|r|r|r|r|}
\hline \multirow{2}{*}{$\begin{array}{l}\text { Types of } \\
\text { incentives }\end{array}$} & \multicolumn{5}{|c|}{ Incentives that encouraged } & \multicolumn{5}{|c|}{ Incentives that would encourage } \\
\cline { 2 - 14 } & Mean & Q25 & MDN & Q75 & CV & SK & Mean & Q25 & MDN & Q75 & CV & SK \\
\hline TAN & 3.19 & 2 & 3 & 4 & 0.28 & -0.71 & 3.23 & 3 & 3 & 4 & 0.26 & -0.13 \\
\hline ACT & 3.49 & 3 & 4 & 4 & 0.24 & 0.19 & 3.18 & 3 & 3 & 4 & 0.27 & 0.59 \\
\hline SOC & 3.30 & 2 & 3 & 4 & 0.35 & 1.13 & 2.97 & 2 & 3 & 4 & 0.35 & 0.93 \\
\hline TOL & 2.86 & 2 & 3 & 3 & 0.25 & 0.27 & 2.81 & 2 & 3 & 3 & 0.26 & 0.19 \\
\hline PRO & 2.29 & 2 & 2 & 3 & 0.31 & 0.41 & 2.25 & 2 & 2 & 3 & 0.34 & 0.34 \\
\hline
\end{tabular}

In order to answer the research question Q11 about significant differences between incentives that encouraged and would encourage UK-based prosumers to engage in knowledge sharing, the Mann-Whitney $U$ test was used. The test results presented in Table 10 did not show any significant differences between incentives in such cases like tangible, tool-related, and promotion-related incentives. Whereas, there were significant differences between incentives in case of activity and social incentives. 
Table 10: The Mann-Whitney test results for incentives that encouraged and would encourage UK-based prosumers to engage in knowledge sharing

\begin{tabular}{|l|r|r|r|r|r|}
\hline $\begin{array}{l}\text { Types of } \\
\text { incentives }\end{array}$ & \multicolumn{1}{|c|}{ TAN } & \multicolumn{1}{|c|}{ ACT } & \multicolumn{1}{c|}{ SOC } & \multicolumn{1}{c|}{ TOL } & \multicolumn{1}{c|}{ PRO } \\
\hline $\mathbf{Z}$ & -0.04 & 2.65 & 2.04 & 0.84 & 0.88 \\
\hline $\mathbf{p}$ value & 0.97 & 0.01 & 0.04 & 0.40 & 0.38 \\
\hline
\end{tabular}

The detailed analysis (Appendix 2) shows that:

- Activity incentives would less likely encourage UK-based prosumers (Mean=3.18; $\mathrm{MDN}=3 ;$ Mode=3) than encouraged them in the past (Mean=3.49; MDN=4; Mode=3);

- Social incentives would less likely encourage UK-based prosumers (Mean=2.97; $\mathrm{MDN}=3 ;$ Mode=2) than encouraged them in the past (Mean=3.30; MDN=3; Mode=2).

\section{Discussion of Research Findings}

The business environment places pressure on businesses to recognize how to adopt communication practices to realize opportunities for change and implement incentives as part of the business offer specifically to improve access to customers and more recently to engage with consumers. The survey responses lead to five research hypotheses formulated and statistically tested and the results summarized in Table 11. Using the data for Mann-Whitney U test, we were able to accept or reject the hypotheses. The choice of incentives through ICT delivery provides opportunities for business to improve understanding of their customers (Lee et al., 2006). This study supports the need for business to recognize the incentives in use and expected to be used by prosumers to ensure improved knowledge sharing capabilities and improved engagement with customers.

Table 11: Summary of hypotheses testing

\begin{tabular}{|l|l|}
\hline \multicolumn{1}{|c|}{ Hypothesis } & \multicolumn{1}{|c|}{ Results } \\
\hline $\begin{array}{l}\text { H1: There are statistically significant differences between Polish and UK-based } \\
\text { prosumers in incentives that encouraged them to engage in knowledge sharing }\end{array}$ & Partially supported \\
\hline $\begin{array}{l}\text { H2: There are statistically significant differences between Polish and UK-based } \\
\text { prosumers in incentives that would encourage them to engage in knowledge sharing }\end{array}$ & Supported \\
\hline $\begin{array}{l}\text { H3: There are statistically significant differences between incentives that encouraged } \\
\text { and would encourage Polish and UK-based prosumers (combined) to engage in } \\
\text { knowledge sharing }\end{array}$ & Supported \\
\hline $\begin{array}{l}\text { H4: There are statistically significant differences between incentives that encouraged } \\
\text { and would encourage Polish prosumers to engage in knowledge sharing }\end{array}$ & Supported \\
\hline $\begin{array}{l}\text { H5: There are statistically significant differences between incentives that encouraged } \\
\text { and would encourage UK-based prosumers to engage in knowledge sharing }\end{array}$ & Partially supported \\
\hline
\end{tabular}

It was clear from the statistical results that the Polish prosumers were mainly encouraged by activity incentives followed to a slightly lesser degree by tangible and social incentives. Given 
the overall median values, it was interesting that all incentives were encouraging to prosumers. There was no strong opinion about an incentive that prompted highest engagement, but perhaps they had not been given choices by business and so were unable to gauge which incentive encouraged them. Also, the low mean value and steady median may suggest that Polish prosumers did not have a clear opinion about the choice of incentives that encouraged them in the past to engage in knowledge sharing.

The findings also indicated that for UK-based prosumers there were no significant differences between tangible, tool-related, and promotion-related incentives. They were also encouraged by activity and social incentives to engage in knowledge sharing. The statistical tests showed there were no significant differences between Polish and UK-based prosumers in the case of tangible, activity, social and tool-related incentives but there was a statistical difference in promotionrelated incentives between Polish and UK-based prosumers. Perhaps this is early days in expecting prosumers to engage in types of co-creating promotional materials after all this is the role of the business more so than the prosumer.

The H1 hypothesis was partially supported showing statistically significant differences between Polish and UK-based prosumers in incentives that encouraged them to engage in knowledge sharing. Also the $\mathrm{H} 2$ hypothesis was supported indicating that there are statistically significant differences between Polish and UK-based prosumers in the particular choice of incentives that encouraged them to engage in knowledge sharing, particularly in tangible, activity, social, and promotion-related incentives. Specifying incentives that would encourage prosumers to engage in knowledge sharing, it was found that for Polish prosumers, the tangible incentives would encourage most to engage in knowledge sharing. To a lesser extent, they would not be encouraged by tool-related and promotion-related incentives.

The H3 hypothesis was supported indicating that there are statistically significant differences between incentives that encouraged and would encourage Polish and UK-based prosumers (combined) to engage in knowledge sharing. However, in terms of incentives that would encourage Polish prosumers tangible incentives are of most interest. However, all types of incentives were indicated as being accepted by Polish prosumers and would encourage them to share knowledge.

The findings indicated that UK-based prosumers had a similar view of incentives that encouraged and would encourage them to engage in knowledge sharing, but in the case of activity and social incentives which were seen as incentives in the past these would not be viewed positively as incentives in the future. These were incentives which would less likely encourage UK-based prosumers in the future. This is interesting suggesting that perhaps these incentives did not meet their needs or they would be hesitant to share knowledge and certainly would not be encouraged by them to share knowledge in the future.

Specifying significant association between incentives that encouraged and would encourage prosumers to engage in knowledge sharing, as well as between incentives that encouraged and would encourage Polish and UK-based prosumers. For the Polish prosumers, each of the choice of incentives showed a higher likelihood for encouraging prosumers engagement than had done in the past. 
The H4 hypothesis was supported indicating that there are statistically significant differences between incentives that encouraged and would encourage Polish prosumers to engage in knowledge sharing. However, the H5 hypothesis was only partially supported showing there are statistically significant differences between incentives that encouraged and would encourage UK-based prosumers to engage in knowledge sharing. Further, for UK prosumers their original incentive choices specifically activity and social incentives were seen as less of an enticement and these particular incentives would not encourage them to engage in knowledge sharing in the future. These findings are interesting and point to the choices business need to make in gauging the incentives that meet the time and circumstances to engage appropriately with prosumers for both parties to benefit.

\section{Conclusions}

\section{Research Contribution}

This work contributes to extant research on prosumption by:

- indicating incentives that encouraged prosumers to engage in knowledge sharing;

- indicating incentives that would encourage prosumers to engage in knowledge sharing; and

- identifying significant association between incentives encouraged and would encourage prosumers to engage in knowledge sharing, as well as between incentives that encouraged and would encourage Polish and UK-based prosumers.

This work contributes to existing research on prosumption, especially prosumers' willingness to share knowledge. The specific incentives identified in this study relate to their exchange with the customer for specific incentives, especially tangible ones, i.e., financial and material rewards, testing of prototypes, free samples of products, low transaction costs for participation, and bonus points with financial value. Intangible incentives named activity incentives are viewed by prosumers as less important than tangible ones.

The study indicated the prosumers interest in business initiatives and addressed incentives from the customer's engagement in adjustment of products/services to meet their needs, improvement of products/service quality and cooperating with well-known enterprises. It was interesting in this study that prosumers regard social incentives as a less important enticement, and this involved cooperation with people who share passions, skills, knowledge and experience, build peer recognition, status, reputation, strengthened social ties with enterprises and customers.

At the same time, promotion-related and tool-related incentives have the least important influence on prosumers knowledge sharing. The promotion-related incentives include co-creating promotional materials, promotional or advertising campaign in various media, promotional information found accidentally, while the tool-related incentives include utilization of interesting and innovative ICTs, invitation by e-mail, invitation by Facebook, interesting blog, interesting video on YouTube, online games. These incentives are ICT intensive and the style of communication and methods of delivery may not be meeting the prosumers needs in a business setting yet they are used widely in social and entertainment settings. 
A second result that should be noted refers to prosumers expectations of incentives offered by enterprises. It appears that prosumers expectations vary depending on the incentives offered to them by the enterprises. The enterprises who offer intangible incentives such as, activity incentives to encourage prosumer engagement were not as interesting to prosumers as the tangible incentives.

A third result to examine are the significant associated resulting from the demographic characteristics pf the prosumers. The demographics captured relate to gender, age, educational background and place of residence. There appears to be interesting relationships revealed between gender of prosumer and the types of incentives offered, between generation and tangible incentives; as well as between educational background and tangible, activity, social and toolrelated incentives. However, there were no particular relationships revealed that create associations between prosumers place of residence and types of incentives; or between generation and activity, social, tool- and promotion-related incentives; as well as between educational background and promotion-related incentives.

The results suggested that women who are categorized into generation $\mathrm{Z}$ and have a secondary education had a greater expectation for tangible incentives than men, or of other generations, and individual with other educational backgrounds. Also, the activity incentives were also closely associated with women prosumers who held a secondary education than other prosumers. Finally, the social incentives were seen to be more favored by women than by men, and from those prosumers who hold a secondary education as opposed to other types of education.

\section{Implication for Research and Practice}

This study can be useful for researchers. They may use this methodology and do similar analyses with different sample in Poland, the UK, and other countries. In addition, many comparisons between different groups and countries can be made. Moreover, the methodology constitutes a very comprehensive basis for identifying incentives that can encourage prosumers to engage in knowledge sharing, but researchers may develop, verify and improve this methodology and its implementation. In addition, researchers may use these research findings and employ them in studies of enterprises. Their goal could be the analysis of incentives offered to prosumers be enterprises from the possibilities for adjusting the incentives to the expectations of prosumers. Moreover, for practitioners, the results of this study can be used to improve activities aimed at prosumption adoption, especially helping them understand which incentives can encourage prosumers to engage in knowledge sharing.

\section{Limitation and Future Research}

The study also has some limitations. The selection of survey respondents needs to be considered in light of the results, as they indicated that the majority of the respondents were young individuals below 35 years in Poland. In this case it is advisable to extend the research study to widen the age participation, and it would be useful to broaden the study to research elderly individuals, such as prosumers above age 50 years.

A second limitation relates to the methodology approach. The current study considered prosumer's only rather than broadening the study to include enterprises. An intention will be to include enterprises in a further study. The issue of sample size can pose a problem especially to determine the most suitable choice of statistical methods to apply. In response, a third limitation 
relates to addressing the internal consistency of variables, reliability and sample size issues as there are suitable statistical approaches that can be used to test these, but the scale of measurement in this study adopted the Likert scale - that is the ordinal scale which was appropriate for the Mann-Whitney $U$ test. Otherwise a t-test can be applied if the scale of measurement is for continuous variables, and report the standard error of the estimates of the means for each group which can handle unequal sample sizes (Chernick \& LaBudde, 2012), and internal consistency and reliability must then be tested with an estimate of the confidence interval (Coe, 2002, Louangrath, 2013).

As stated by (Doğan \& Doğan, 2015) pp.103-107 the Mann-Whitney U test is most effective considering Fraser efficiency value even in non-stable conditions where samples are of considerably different sizes. However, it is argued in (Toothaker, 1971) that there were observed comparable power values of non-parametric Mann-Whitney $U$ test and permutation t-test combined with samples of considerably different sizes. To respond to these views, a t-test is also

Table 12: The t-test results for incentives that would encourage Polish and UK-based prosumers to engage in knowledge sharing while using regular t-test

\begin{tabular}{|l|r|r|r|r|r|}
\hline Types of incentives & \multicolumn{1}{l|}{ TAN } & \multicolumn{1}{l|}{ ACT } & \multicolumn{1}{c|}{ SOC } & \multicolumn{1}{c|}{ TOL } & \multicolumn{1}{c|}{ PRO } \\
\hline $\mathbf{t}$ & 8.30 & 3.06 & 4.15 & -1.92 & 5.36 \\
\hline p value & 0.00 & 0.00 & 0.00 & 0.05 & 0.00 \\
\hline Mean - Mean $_{2}\left(\mathbf{C I}_{\mathbf{L}} ; \mathbf{C I}_{\mathbf{U}}\right)$ & 0.51 & 0.20 & 0.35 & -0.13 & 0.38 \\
\hline Cohen's d (effect size) & $(0.38 ; 0.65)$ & $(0.06 ; 0.34)$ & $(0.18 ; 0.52)$ & $(-0.26 ; 0.01)$ & $(0.25 ; 0.51)$ \\
\hline Glass' delta (effect size) & 0.66 & 0.24 & 0.34 & -0.16 & 0.47 \\
\hline
\end{tabular}

reported to avoid the problems associated with the use of the Likert scale. The assumptions for the Likert scale was to treat the data as continuous with only special values recorded. That could be conditionally accepted when samples are large enough. As stated in (de Winter \& Dodou, 2010) the t-test and Mann-Whitney U test generally have equivalent power and also regular t-test is to be recommended over the unequal variances t-test. Due this accepted view the t-test was conducted for the special large sample with unequal size of 783 and 171 scores. The test confirmed the results of Mann-Whitney U test and also by the effect size reported by Cohen's and Glass' delta (for unequal variances). The final limitation relates to the scope of the prosumer study, as the present study integrated all forms of prosumer knowledge sharing activities in one category that included evaluating products/services, commenting, testing, upgrading, and creating products or services.

A further study would attempt to conduct a more in-depth assessment on specific forms of prosumer engagement in different categories that relate to the various incentives expected by them for each knowledge sharing activity. These issues should be carefully considered and assimilated in the future works. 


\section{Acknowledgement}

This research has been supported by a grant entitled "Transformation of business and public administration by information technology and information systems" from the University of Economics in Katowice, Poland, 2014-2016. 


\section{Appendix 1: Conceptual framework of incentives}

\begin{tabular}{|c|c|c|}
\hline $\begin{array}{l}\text { Type of } \\
\text { incentives }\end{array}$ & Symbol & Items \\
\hline TAN & $\begin{array}{l}\text { TAN1 } \\
\text { TAN2 } \\
\text { TAN3 } \\
\text { TAN4 } \\
\text { TAN5 } \\
\text { TAN6 }\end{array}$ & $\begin{array}{l}\text { Financial rewards } \\
\text { Coupons, sweepstakes } \\
\text { Free usage (testing) of prototypes } \\
\text { Free samples of products } \\
\text { Low transaction costs for participation } \\
\text { Bonus points with financial value }\end{array}$ \\
\hline ACT & $\begin{array}{l}\text { ACT1 } \\
\text { ACT2 } \\
\text { ACT3 } \\
\text { ACT4 } \\
\text { ACT5 }\end{array}$ & $\begin{array}{l}\text { Participating in interesting initiatives } \\
\text { Adjustment of products/services to own needs } \\
\text { Increase/decrease of satisfaction with enterprises and their } \\
\text { products/services } \\
\text { Cooperation with well-known enterprises } \\
\text { Improvement of the products/services quality }\end{array}$ \\
\hline SOC & $\begin{array}{l}\text { SOC1 } \\
\text { SOC2 } \\
\text { SOC3 }\end{array}$ & $\begin{array}{l}\text { Cooperation with people who share passions, skill, knowledge, and } \\
\text { experience } \\
\text { Building peer recognition, status, and reputation } \\
\text { Strengthening social ties with enterprises and their customers }\end{array}$ \\
\hline TOL & $\begin{array}{l}\text { TOL1 } \\
\text { TOL2 } \\
\text { TOL3 } \\
\text { TOL4 } \\
\text { TOL5 } \\
\text { TOL6 }\end{array}$ & $\begin{array}{l}\text { Utilization of innovative and interesting information and communications } \\
\text { technology (ICT) } \\
\text { Invitation by e-mail } \\
\text { Invitation by Facebook } \\
\text { Interesting blog } \\
\text { Interesting video on YouTube } \\
\text { Online game }\end{array}$ \\
\hline PRO & $\begin{array}{l}\text { PRO1 } \\
\text { PRO2 } \\
\text { PRO3 }\end{array}$ & $\begin{array}{l}\text { Co-creating promotional materials } \\
\text { Promotional or advertising campaign on various media } \\
\text { Promotional information found accidentally }\end{array}$ \\
\hline
\end{tabular}




\section{Appendix 2: Descriptive statistics}

\begin{tabular}{|c|c|c|c|c|c|c|c|c|c|c|c|c|}
\hline $\begin{array}{l}\text { Type of } \\
\text { incentives }\end{array}$ & $\begin{array}{l}\text { E/ } \\
\text { WE } \\
\end{array}$ & Cou. & Mean & Q25 & MDN & Q75 & VAR & SD & CV & SK & CK & Mode \\
\hline \multirow{6}{*}{ TAN } & E & UK & 3.19 & 2 & 3 & 4 & 0.82 & 0.91 & 0.28 & -0.71 & -0.62 & 4 \\
\hline & $\mathrm{E}$ & PL & 2.78 & 2 & 3 & 4 & 1.08 & 1.04 & 0.37 & 1.71 & -0.92 & 1 \\
\hline & E & Com & 2.84 & 2 & 3 & 4 & 1.06 & 1.03 & 0.36 & 1.79 & -0.85 & 1 \\
\hline & WE & UK & 3.23 & 3 & 3 & 4 & 0.69 & 0.83 & 0.26 & -0.13 & -0.46 & 3 \\
\hline & WE & PL & 3.74 & 3 & 4 & 4 & 0.50 & 0.71 & 0.19 & 0.10 & 2.05 & 4 \\
\hline & WE & Com & 3.65 & 3 & 4 & 4 & 0.57 & 0.76 & 0.21 & -0.03 & 1.06 & 4 \\
\hline \multirow{6}{*}{ ACT } & E & UK & 3.49 & 3 & 4 & 4 & 0.68 & 0.83 & 0.24 & 0.19 & -0.75 & 3 \\
\hline & E & PL & 3.08 & 3 & 3 & 4 & 0.64 & 0.80 & 0.26 & 0.10 & 0.16 & 3 \\
\hline & E & Com & 3.15 & 3 & 3 & 4 & 0.67 & 0.82 & 0.26 & 0.18 & 0.08 & 3 \\
\hline & WE & UK & 3.18 & 3 & 3 & 4 & 0.76 & 0.87 & 0.27 & 0.59 & -0.46 & 3 \\
\hline & WE & PL & 3.38 & 3 & 4 & 4 & 0.55 & 0.74 & 0.22 & -0.39 & 1.01 & 4 \\
\hline & WE & Com & 3.35 & 3 & 3 & 4 & 0.59 & 0.77 & 0.23 & -0.42 & 0.54 & 4 \\
\hline \multirow{6}{*}{ SOC } & E & UK & 3.30 & 2 & 3 & 4 & 1.32 & 1.15 & 0.35 & 1.13 & -1.30 & 2 \\
\hline & E & PL & 2.74 & 2 & 3 & 3 & 0.93 & 0.97 & 0.35 & 0.77 & -0.40 & 2 \\
\hline & E & Com & 2.83 & 2 & 3 & 3 & 1.04 & 1.02 & 0.36 & 0.82 & -0.53 & 2 \\
\hline & WE & UK & 2.97 & 2 & 3 & 4 & 1.09 & 1.04 & 0.35 & 0.93 & -0.72 & 2 \\
\hline & WE & PL & 3.32 & 3 & 3 & 4 & 0.98 & 0.99 & 0.30 & -0.69 & -0.30 & 4 \\
\hline & WE & Com & 3.26 & 3 & 3 & 4 & 1.02 & 1.01 & 0.31 & -0.74 & -0.55 & 4 \\
\hline \multirow{6}{*}{ TOL } & $\mathrm{E}$ & UK & 2.86 & 2 & 3 & 3 & 0.49 & 0.70 & 0.25 & 0.27 & -0.24 & 3 \\
\hline & E & PL & 2.39 & 2 & 2 & 3 & 0.74 & 0.86 & 0.36 & 0.45 & -0.75 & 2 \\
\hline & $\mathrm{E}$ & Com & 2.46 & 2 & 2 & 3 & 0.73 & 0.85 & 0.35 & 0.54 & -0.79 & 2 \\
\hline & WE & UK & 2.81 & 2 & 3 & 3 & 0.54 & 0.74 & 0.26 & 0.19 & 0.60 & 3 \\
\hline & WE & PL & 2.67 & 2 & 3 & 3 & 0.73 & 0.86 & 0.32 & -0.38 & -0.13 & 3 \\
\hline & WE & Com & 2.70 & 2 & 3 & 3 & 0.70 & 0.84 & 0.31 & -0.36 & -0.04 & 3 \\
\hline \multirow{6}{*}{ PRO } & E & UK & 2.29 & 2 & 2 & 3 & 0.51 & 0.71 & 0.31 & 0.41 & 2.02 & 2 \\
\hline & E & PL & 2.24 & 2 & 2 & 3 & 0.75 & 0.87 & 0.39 & 0.27 & -0.37 & 2 \\
\hline & $\mathrm{E}$ & Com & 2.24 & 2 & 2 & 3 & 0.71 & 0.84 & 0.37 & 0.29 & -0.14 & 2 \\
\hline & WE & UK & 2.25 & 2 & 2 & 3 & 0.57 & 0.76 & 0.34 & 0.34 & 2.16 & 2 \\
\hline & WE & PL & 2.64 & 2 & 3 & 3 & 0.75 & 0.87 & 0.33 & 0.74 & -0.19 & 2 \\
\hline & WE & Com & 2.57 & 2 & 3 & 3 & 0.74 & 0.86 & 0.33 & 0.66 & -0.09 & 2 \\
\hline
\end{tabular}

Abbreviations: $\mathrm{E}$ - incentives that encouraged prosumers, WE - incentives that would encourage prosumers, Cou. - Country: PL - Poland, UK - United Kingdom, Com - Combined. 


\section{References}

Aghamirian, B., Dorri, B., \& Aghamirian, B. (2013). Effects of customer knowledge management's eight factors in e-commerce. Management Science and Engineering, 7(4), $1-11$.

Almahamid, S., McAdams, A. C., \& Kalaldeh, T. (2010). The relationships among organizational knowledge sharing practices, employees' learning commitments, employees' adaptability, and employees' job satisfaction: An empirical investigation of the listed manufacturing companies in Jordan. Interdisciplinary Journal of Information, Knowledge, and Management, 5, 327-325.

Bencsik, A., Juhász, T., \& Machova, R. (2014). Mentoring practice on behalf of knowledge sharing in the light of education. Acta Polytechnica Hungarica, 11(9), 95-114.

Brabham, D. C. (2012). Motivations for participation in a crowdsourcing application to improve public engagement in transit planning. Journal of Applied Communication Research, 40(3), 307-328.

Bylok, F. (2013). Konsumpcja, konsument i społeczeństwo konsumpcyjne we współczesnym s'wiecie [Consumption, the consumer and the consumer society in the modern world]. Katowice: Śląsk.

Cheng, M. Y., Ho, J. S. Y., \& Lau, P. M. (2009). Knowledge sharing in academic institutions: A study of multimedia university Malaysia. Electronic Journal of Knowledge Management, 3(7), 313-324.

Chernick, M. R., \& LaBudde, R. A. (2012). An introduction to bootstrap methods with applications to R. New Jersey: John Wiley \& Sons.

Chouikha, M. B. (2016). Organizational design for knowledge management. London, UK: John Wiley \& Sons.

Coe, R. (2002). It's the effect size, stupid. What effect size is and why it is important? Annual Conference of the British Educational Research Association, University of Exeter, England, 12-14 September 2002. Retrieved March 30, 2017 from https://www.leeds.ac.uk/educol/documents/00002182.htm.

Croteau, A. M., \& Li, P. (2003). Critical success factors of CRM technological initiatives. Canadian Journal of Administrative Sciences, 20(1), 21-34.

Dermol, V. (2011). Incentives for knowledge management and organisational performance. Proceedings of Management, Knowledge and Learning International Conference MakeLear, 22-24 June 2011, Celje, Slovenia, 345-353.

DeVellis, R.F., (2003). Scale development: Theory and applications: theory and application. Thousand Oaks, California: Sage Publications.

De Vries, R. E., Van den Hooff, B., \& De Ridder, J. A. (2006). Explaining knowledge sharing: The role of team communication styles, job satisfaction and performance beliefs. Communication Research, 33(2), 115-135. 
Doğan, I., \& Doğan, N. (2015). The effect of sample size on expected value, variance and Fraser efficiency for nonparametric independent two sample test. Turkiye Klinikleri Journal of Biostatistics, 7(2), 103-107.

Gafni, R., Geri, N., \& Bengov, P. (2014). Investigating the effect of tangible and virtual rewards on knowledge contribution in online communities. Online Journal of Applied Knowledge Management, 2(2), 1-11.

Gammelgaard, J. (2007). Why not use incentives to encourage knowledge sharing? Journal of Knowledge Management Practice, 8(1). Retrieved from http://www.tlainc.com/articl127.htm

Gibbert, M., Leibold, M., \& Probst, G. (2002). Five styles of customer knowledge management, and how smart companies use them to create value. European Management Journal, 20(5), 459-469.

Greenberg, J., \& Liebman, M. (1990). Incentives: The missing link in strategic performance. Journal of Business Strategy, 11(4), 8-11.

Grubić-Nešić, L., Matić, D., \& Mitrović, S. (2015). The influence of demographic and organizational factors on knowledge sharing among employees in organizations. Tehnički Vjesnik, 22(4), 1005-1010.

Grudzewski, W. M., Hejduk, I. K., Sankowska, A., \& Wańtuchowicz, M. (2013). Sustainability w biznesie czyli przedsiębiorstwo przyszłości. Zmiany paradygmatów i koncepcji zarzadzania [Sustainability in business i.e., enterprise of the future. Paradigms and management concepts changes]. Warszawa: Poltex.

Gustafsson, A., Kristensson, P., Löfgren, M., \& Witell, L. (2011). Idea generation: customer cocreation versus traditional market research techniques. Journal of Service Management, $22(2), 140-159$.

Hall, H. (2001). Social exchange for knowledge exchange. Paper presented at Managing knowledge: conversations and critiques, University of Leicester Management Centre, 1011 April 2001, Retrieved January 10, 2017 from https: //drhazelhall.files.wordpress.com/ 2013/01/2001_hall_social_ex_for_kn_ex_leicester.pdf

Hawkins, D. I., Best, R. J., \& Coney, K. A. (2001). Consumer behavior: Building marketing strategy. Boston, MA: Irwin/McGraw Hill.

Hijazi, H. A., \& Salamah, H. (2014). Impact of social capital on knowledge sharing at the public sector in Jordan. Information and Knowledge Management, 4(1), 20-30.

Hinton, P. (2004). Statistics explained: A guide for social science students. New York, NY: Routledge.

Ho, L. A., \& Kuo, T. H. (2013). How system quality and incentive affect knowledge sharing. Industrial Management \& Data Systems, 113(7), 1048-1063.

Humphreys, A., \& Grayson, K. (2008). The intersecting roles of consumer and producer: A critical perspective on co-production, co-creation and prosumption. Sociology Compass, 2(3), 963-980. Retrieved from http://www.kentgrayson.com. 
Ikechukwu, F. A. Daubry, M. P., \&, Chijindu, H. I. (2012). Consumer attitude: Some reflections on its concept, trilogy, relationship with consumer behavior and marketing implications. European Journal of Business and Management, 4(13), 38-51.

Iyer, G. S., \& Ravindran, S. (2009). Usefulness, incentives and knowledge management. Journal of Knowledge Management, 13(6), 410-430.

Janzik, L. (2010). Contribution and participation in innovation communities: A classification of incentives and motives. International Journal of Innovation and Technology Management, 7(3), 247-262.

Janzik, L., \& Herstatt, C. (2008). Innovation communities: Motivation and incentives for community members to contribute. Proceedings of the 4th IEEE International Conference on Management of Innovation and Technology, 21-24 September 2008, Bangkok, Thailand, 350-355.

Jurgenson, N., \& Ritzer, G. (2009). Efficiency, effectiveness, and Web 2.0. In S. Kleinman (Ed.), The culture of efficiency. New York, NY: Peter Lang Publishing, 51-67.

Kisielnicki, J. (2014). Zarządzanie. Jak zarządzać i być zarzadzanym [Management. How to manage and be managed]. Warszawa: PWE.

Krupski, R. (2014). Zasoby niematerialne jako główny składnik strategii przedsiębiorstwa działającego w turbulentnym, nieprzewidywalnym otoczeniu [Intangible resources as a main component of the business strategy in turbulent, unpredictable environment]. Organizacja i Kierowanie [Organization and Management], 1A(159), 87-98.

Lam, A., \& Lambermont-Ford, J. P. (2010). Knowledge sharing in organisational contexts: A motivation-based perspective. Journal of Knowledge Management, 14(1), 51-66.

Leadbeater, C. (2008). We-think. Mass innovation, not mass production. London, UK: Profile Books.

Lee, M. K. O., Cheung, C. M. K., Lim, K. H., \& Sia, C. L. (2006). Understanding customer knowledge sharing in web-based discussion boards: An exploratory study. Internet Research, 16(3), 289-303.

Liebowitz, J. (2003). A knowledge management strategy for Jason organization: A case study. Journal of Computer Information Systems, 44(2), 1-5.

Löcker, A. K., Eraßme, D., Jakobs, E. M., Schaar, A. K., Valdez, A. C., \& Ziefle. M. (2014). Yet another platform? Motivational factors for using online communities in business contexts. Proceedings of the 5th International Conference on Applied Human Factors and Ergonomics AHFE 2014, 19-23 July 2014, Krakow, Poland, 1145-1156.

Louangrath, P. I. (2013). Survey reliability \& instrument calibration. Retrieved from https://papers.ssrn.com/sol3/papers.cfm?abstract_id=2225810.

McCrindle, M. (2014). The ABC of XYZ. Understanding of global generations. Bella Vista: McCrindle Research.

Morrison, S. \& Crane, F. G. (2007). Building the service brand by creating and managing an emotional brand experience. Journal of Brand Management, 14, 410-421. 
Mróz, B. (2013). Konsument w globalnej gospodarce. Trzy perspektywy [Consumer in the global economy. Three approaches]. Warszawa: Szkoła Główna Handlowa Press.

Nasri, G. (2012). Why consumers are increasingly eager to trade data for personalization. Retrieved March 01, 2014 from http://www.digitaltrends.com/social-media/whyconsumers-are-increasingly-eager-to-trade-data-for-personalization

Nogalski, B., \& Niewiadomski, P. (2013). Absorbcja wiedzy inżynierskiej w praktyce zarządzania - kontekst strategii przywództwa kosztowego [Absorption of the engineering knowledge in management practice]. Organizacja i Kierowanie [Organization and Management], 5(158), 11-29.

Premazzi, K., Castaldo, S., Grosso, M., Raman, P., Brudvig, S., \& Hofacker, C. F. (2010). Customer information sharing with e-vendors: The roles of incentives and trust. International Journal of Electronic Commerce, 14(3), 63-91.

Reitz, A. (2012). Social media's function in organizations: A functional analysis approach. Global Media Journal, 5(2), 41-56.

Ritzer, G., \& Jurgenson, N. (2010). Production, consumption, prosumption: The nature of capitalism in the age of the digital 'prosumer'. Journal of Consumer Culture, 10(1), 13-36.

Ryan, R.M., \& Deci, E.L. (2000). Intrinsic and extrinsic motivations: Classic definitions and new directions. Contemporary Educational Psychology, 25, 54-67.

Sinclaire, J. K., \& Vogus, C. E. (2011). Adoption of social networking sites: An exploratory adaptive structuration perspective for global organizations. Information Technology and Management, 12(4), 294-314.

Siuda, P. (2012). Mechanizmy kultury prosumpcji, czyli fani i ich globalne zróżnicowanie [Mechanisms of prosumption culture, i.e., the fans and their global diversity]. Studia Socjologiczne, 4(207), 109-132.

Sopińska, A., \& Wachowiak, P. (2015). Kultura organizacyjna a gotowość pracowników do dzialenia się wiedzą [Organizational culture and the willingness of employees to share knowledge]. In K. Perechuda \& I. Chomiak-Orsa (Eds.), Wiedza i informacja $w$ akceleracji biznesu [Knowledge and information to accelerate business], 31-40, Częstochowa: Wydział Zarządzania Politechniki Częstochowskiej Press.

Taherparvar, N., Esmaeilpour, R., \& Dostar, M. (2014). Customer knowledge management, innovation capability, and business performance: A case study of the banking industry. Journal of Knowledge Management, 3(18), Retrieved May 12, 2014 from http://www.emeraldinsight.com/journals.htm?issn=1367-3270\&volume $=18 \&$ issue $=3$

Tapscott, D., \& Williams, A. D. (2006). Wikinomics: How mass collaboration changes everything. New York, NY: Penguin Group.

Thomson, M., MacInnis, D. J., \& Park, C. W. (2005). The ties that bind: Measuring the strength of consumers' emotional attachments to brands. Journal of Consumer Psychology, 1(15), 77-91. 
Tian, F., Liu, B., Sun, X., Zhang, X., Cao, G., \& Lin, G. (2017). Movement-based incentive for crowdsourcing. IEEE Transactions on Vehicular Technology, PP(99), 1-17. doi: 10.1109/TVT.2017.2654355.

Toothaker, L. E. (1971). An empirical investigation of the effect of unequal variations on the permutations t-test. Annual Meeting of the American Educational Research Association, New York, NY: US Department of Health Education and Welfare.

Tong, C., Tak, W. I. W., \& Wong, A. (2013). The impact of knowledge sharing on the relationship between organizational culture and job satisfaction: The perception of information communication and technology (ICT) practitioners in Hong Kong. International Journal of Human Resource Studies, 1(3), 9-37.

Tsai, W., Tsai, M., Li, S., \& Lin, C. (2012). Harmonizing firms' knowledge and strategies with organizational capabilities. Journal of Computer Information Systems, 53(1), 23-32.

Van Aken, T., Camps, T., \& Jurgens, B. (1998). Organiseren van denkwerk. Van Gorcum.

Van den Hooff, B., De Ridder, J., \& Aukema, E. (2004). Exploring the eagerness to share knowledge: The role of social capital and ICT in knowledge sharing. In M. Huysman \& V. Wulf (Eds.), Social Capital and Information Technology, 7, 163-186. Cambridge: The MIT Press.

Vuori, V., \& Okkonen, J. (2012). Knowledge sharing motivational factors of using an intraorganizational social media platform. Journal of Knowledge Management, 16(4), $592-$ 603.

Winter de, J. C. F., \& Dodou, D. (2010). Five-point Likert items: t test versus Mann-WhitneyWilcoxon. Practical Assessment, Research \& Evaluation, 15(11), 1-16.

Xie, C., Bagozzi, R. P., \& Troye, S. V. (2008). Trying to prosume: Toward a theory of consumers as co-creators of value. Journal of the Academy of Marketing Science, 36, 109-122.

Yuan, D., Lin, Z., \& Zhuo, R. (2016). What drives consumer knowledge sharing in online travel communities? Computer in Human Behavior, 63(C), 68-74.

Ziemba, E., \& Eisenbardt, M. (2014). Prosumers' eagerness for knowledge sharing with enterprises - a Polish study. Online Journal of Applied Knowledge Management, 2(1), 40-58.

Ziemba, E., \& Eisenbardt, M. (2015). Prosumers' participation in business processes. Online Journal of Applied Knowledge Management, 3(1), 114-127.

Ziemba, E., \& Eisenbardt, M. (2016). Incentives encouraging prosumers to knowledge sharing framework based on Polish study. Online Journal of Applied Knowledge Management, $4(2), 40-58$. 


\section{Authors' Biographies}

Ewa Ziemba completed her Ph.D. and Post Ph.D. in Management, with a major focus on management information systems. She is an Associate Professor at the University of Economics, Katowice, Poland. Her current research focuses on information systems and technologies for business and public administration transformation. She has published over 170 peer-reviewed papers and 18 books, and has played an instrumental role in prestigious Polish and international research projects. Ewa Ziemba serves on the editorial boards of several international journals, is the Founding Editor-in-Chief of The Online Journal of Applied Knowledge Management, and I the Editor-in-Chief of Journal of Economics and Management. She is also the Vice President for Research Collaborations of the International Institute for Applied Knowledge Management. Ewa Ziemba has received numerous awards for research and teaching, including The Excellent Award of the President of the University of Economics in Katowice, The Silver Cross of Merit from the President of Poland, The Medal of the National Education Commission from the Ministry of National Education in Poland, The Award of Fellow \& Distinguished Scholar and The Excellence in Research \& Scholarship Award from the International Institute for Applied Knowledge Management, and several The Best Papers awards.

Monika Eisenbardt completed her Ph.D. with a major focus on management information systems as well as changes and challenges involving modern consumers. She is an Assistant Professor at the University of Economics, Katowice, Poland. She has published over 20 peerreviewed pieces including conference papers, book chapters and international journal papers. Her current research focuses on knowledge-based organizations, especially information systems and technologies for prosumption. Monika serves an editorial secretary function in Journal of Economics and Management - the official journal of University of Economics in Katowice. She has received two Best Paper awards at the international conferences.

Roisin Mullins completed her Ph.D. in the development and evaluation of e-learning systems, learning communities and business training systems. She has published over 40 peer-reviewed pieces including conference papers, book chapters and international journal papers. Roisin Mullins serves on the editorial boards of several international conferences. Her research has emphasized practical solutions to technology problems or novel applications of technology, so that in addition to answering a question, the research outcomes have informed policy and practice guidelines at the European level and decision making processes in the SMEs of EU member countries. She has received several Best Paper awards at the international conferences.

Dariusz Grabara is a Ph.D. student. He completed his MSc. with strong focus on the computer market analysis and prognostic models for desktop computer prices. He is an Assistant at the University of Economics, Katowice. His current research are aimed at the electronic auction platforms with focus on determining crucial variables which affect sellers behavior. He has gained experience during his work for IT companies, banks, and automation industry. 